\title{
First record of Pachycrocuta brevirostris (Gervais, 1850) from Ukraine on the background of the European occurrence of the species
}

\author{
Adrian Marciszak ${ }^{1}$ (D) $\cdot$ Yuriy Semenov ${ }^{2} \cdot$ Piotr Portnicki $^{3} \cdot$ Tamara Derkach $^{4}$
}

Received: 23 July 2020 / Accepted: 18 January 2021 / Published online: 11 February 2021

(C) The Author(s) 2021

\begin{abstract}
Cranial material of Pachycrocuta brevirostris from the late Early Pleistocene site of Nogaisk is the first record of this species in Ukraine. This large hyena was a representative of the Tamanian faunal complex and a single specialised scavenger in these faunas. The revisited European records list of $P$. brevirostris documented the presence of this species in 101 sites, dated in the range of 3.5-0.4 Ma. This species first disappeared in Africa, survived in Europe until ca. 0.8-0.7 Ma, and its last, relict occurrence was known from south-eastern Asia. The main reason of extinction of $P$. brevirostris probably was the competition with Crocuta crocuta. The cave hyena was smaller, but its teeth were proportionally larger to the body size, better adapted to crushing bones and slicing meat, and could also hunt united in larger groups.
\end{abstract}

Keywords Nogaisk $\cdot$ Maxilla $\cdot$ Competition $\cdot$ Occurrence $\cdot$ Extinction $\cdot$ Nogaisk $\cdot$ Maxilar $\cdot$ Competencia $\cdot$ Ocurrencia $\cdot$ Extinción

\section{Resumen}

El material craneal de Pachycrocuta brevirostris de la localidad de Nogaisk del final del Pleistoceno inferior es el primer registro de esta especie en Ucrania. Esta gran hiena es un representante de los carnívoros del complejo faunístico de Tamania y el único carroñero especializado. La lista revisada de registros europeos de $P$. brevirostris documentó la presencia de esta especie en 101 yacimientos datados entre 3.5-0.4 Ma. Esta especie desapareció primero en África, pero sobrevivió en Europa hasta ca. 0.8-0.7 Ma, y su último relicto se conoció en el sudeste asiático. La principal razón de la extinción de $P$. brevirostris fue probablemente la competencia con Crocuta crocuta. La hiena de las cavernas era más pequeña, pero sus dientes eran proporcionalmente más grandes al tamaño del cuerpo por lo que estaban mejor adaptados para triturar huesos y rebanar carne, y también podían unirse en grupos más grandes para cazar.

Palabras clave Nogaisk $\cdot$ Maxilar $\cdot$ Competencia $\cdot$ Ocurrencia $\cdot$ Extinción

Adrian Marciszak

adrian.marciszak@uwr.edu.pl

Yuriy Semenov

paleo@museumkiev.org

Piotr Portnicki

juzek1000@gmail.com

Tamara Derkach

derkachzokm@ukr.net
1 Department of Palaeozoology, Institute of Environmental Biology, Faculty of Biological Sciences, University of Wrocław, Sienkiewicza 21, 50-335 Wrocław, Poland

2 National Museum of Natural History, National Academy of Sciences of Ukraine, Bohdan Khmelnytsky 15, Kyiv 01030, Ukraine

3 European Centre of Palaeontology, University of Opole, Oleska 48, 49-510 Opole, Poland

4 Zaporizhzhia Regional Local History Museum, Troitska 29, Zaporizhzhia 69063, Ukraine 


\section{Introduction}

The Tamanian faunal complex was firstly established by Gromov (1948) based on the presence of large mammals as one of the biochronological units of the East European Pleistocene (Vislobokova and Titov 2020). After the description of the type site, which is Sinyaya Balka on the Tamanian Peninsula in Russia (Gromov 1948), a number of new mammal localities of this complex have been discovered there and within the north-eastern coastal area of the Sea of Azov in Russia, Azerbaijan and Georgia (Vereshchagin, 1957, 1959; Dubrovo 1963; Alekseeva 1977; Vangengeim et al. 1991; Baigusheva 2000; Tesakov 2004; Dodonov et al. 2006; Tesakov et al. 2007, 2013; Baigusheva and Titov 2008; Bukhsianidze et al. 2014; Vislobokova and Titov 2020).

Based on biostratigraphic and paleomagnetic data, the time range of the Tamanian complex sense strict was estimated as ca. 1.2-0.87 Ma (MIS 36 to the MIS 22-21 boundary, equivalent of Western European Epivillafranchian). It approximately corresponds to the interval between the Cobb Mountain paleomagnetic Subchron and the Brunhes/Matuyama Chron boundary (Markova 2007; Vislobokova and Tesakov 2013; Markova and Vislobokova 2016; Vislobokova and Titov 2020). The key species of the Tamanian complex is Mammuthus (Archidiskodon) meridionalis tamanensis Dubrovo, 1964. Other characteristic herbivores includes Equus aff. suessenbornensis Wüst, 1901, Stephanorhinus etruscus (Falconer 1868), and Elasmotherium caucasicum Borissiak, 1914 (Gromov 1948; Vereshchagin 1957; Dubrovo and Alekseev 1964; Alekseeva 1977; Vislobokova and Titov 2020). Among carnivores, the most important taxa include Canis mosbachensis tamanensis (Vereshchagin 1957), Lycaon lycaonoides (Kretzoi 1938), Lutra simplicidens Thenius, 1965, Homotherium latidens (Owen 1846), Acinonyx pardinensis Croizet and Jobert, 1828, and Pachycrocuta brevirostris Gervais, 1850 (Sotnikova et al. 2002; Titov 2008; Sotnikova and Titov 2008).

Stone artefacts from Sinyaya Balka document one of the oldest Palaeolithic human occurrences in Europe (Shchelinsky et al. 2010). In this context, the study of Tamanian faunas is of particular interest for the reconstruction of the ancient human settlement and environment at that time (Vislobokova and Titov 2020). This task requires a revision of faunal lists from particular sites previously assigned to the Tamanian complex, especially the composition of large mammals, as possible resource and competitor species for the Palaeolithic humans (Vislobokova and Titov 2020).

Although different carnivore species for the Tamanian faunal complex from Ukraine were listed in a number of publications (e.g., Topachevsky 1965; Vereshchagin et al.
1971; Kahlke 1975), they have not been properly revised. In this respect, old collections and newly collected materials require a substantial revision and analysis. The main purpose of this article is the re-study of hyena material from Nogaisk stored in the National Museum of Natural History in Kyiv and Zaporizhzhia Regional Local History Museum. Several skull fragments were found on the coast of the Sea of Azov in 1979. Recently it was possible to combine all remains for our study. The individual from Nogaisk locality provided the first occurrence of $P$. brevirostris in the modern territory of Ukraine. Additionally, the study provides a new evidence on morphology and evolution of this species within Eurasia.

\section{Locality and stratigraphy}

A few high coastal sections along the Taganrog Gulf shore expose subaqual sediments such as fluviatile deposits of ancient Don River origin and estuarine deposits of the Sea of Azov. These sediments are overlain by subaerial deposits that primarily belong to the loess-paleosol formation. The underlying subaqual deposits are arranged in three terraces, with the earliest one, the Nogaisk terrace yielding fossil remains of mammals of the Tamanian faunal assemblage. The two others, the Platovo and Voznesenskaya terraces, contain a fauna corresponding to the Middle Pleistocene (Velichko et al. 2010).

The Nogaisk locality is located on the northern coast of the Sea of Azov near Primorsk village (Zaporizhzhia Oblast, Ukraine), $2.5-3 \mathrm{~km}$ to the east from Obitochna foreland. The association of small and large mammals from this locality is characterised mostly by ancient forms, among which only a few were present in the Middle Pleistocene. As for the species list, a significant bias was established for this locality. Large animals are very rarely found, and their remains are usually fragmentary and in bad condition, whereas small mammal remains are quite abundant and well preserved. Fossils were found in a complex of abandoned channel and lacustrine sediments. Two layers, sometimes described as two sites (Nogaisk 1 and 2) were distinguished, but contained the same fauna and were contemporary (Rekovets and Nadachowski 1996; Kowalski 2001). Deposits consisted mainly of layered, partly ferrugineol clayey sand and gravel with small carbonate concretions and/or sandstone pebbles (Kovalchuk et al. 2017).

The mammal assemblage includes 33 species: Erinaceus sp.; Desmana nogaica Topachevsky and Pashkov, 1990; Spermophilus nogaici (Topachevsky 1957); Trogontherium cuvieri Fischer von Waldheim, 1809; Castor fiber Linnaeus, 1758; Sicista vinogradovi Topachevsky 1965; Sicista sp.; Borsodia newtoni (Forsyth Major, 1902); Clethrionomys 
kretzoii (Kowalski, 1958); Allocricetus ehiki Schaub, 1930; Cricetus cricetus (Linnaeus 1758); Ellobius palaeotalpinus Schevtschenko, 1965; Lagurodon arankae (Kretzoi 1942); Mimomys rex Kormos, 1934; Mimomys reidi Hinton, 1910; Mimomys savini Hinton, 1910; Plioscirtopoda stepanovi Schevchenko, 1965; Prolagurus pannonicus Kormos 1930; Pygerethmus pumilio (Kerr, 1792); Spalax minor Topachevsky 1965; Lepus sp.; Ochotona sp.; Canis sp.; Mustela stromeri Kormos, 1934; Mustela palerminea (Petenyi 1864); Mustela praenivalis Kormos, 1934; Pachycrocuta brevirostris (Gervais 1850); Mammuthus meridionalis (Nesti 1825); Equus aff. suessenbornensis Wüst, 1901; Elasmotherium caucasicum Borissiak, 1914; Megaloceros sp.; Bison sp.; Pontoceros ambiguus Vereshchagin et al. 1971 (Topachevsky 1957; Garutt 1954; Kretzoi 1965; Topachevsky 1965; Vereshchagin et al. 1971; Kahlke 1975; Garutt and Foronova 1976; Dubrovo and Kapelist 1979; Topachevsky et al. 1987; Garutt et al. 1990; Rekovets 1994; Rekovets and Nadachowski 1996; Kowalski 2001; Velichko et al. 2010; Popescu 2011; Kolfschoten and Markova 2005; Rekovets et al. 2009; Maschenko et al. 2011; Larramendi 2016; Vislobokova and Titov 2020).

Rekovets and Nadachowski (1996) noted that the predominant species from Nogaisk, constituting up to $60 \%$ of the micromammal assemblage, were representatives of genera Lagurodon, Allophaiomys and Spermophilus. Other taxa belonging to Ellobius (common), Spalacidae or Cricetidae (rarer) retained ancestral, morphological characters. Allactaginae were diverse, but not very common, also as Spalax and Prolagurus forms (Rekovets and Nadachowski 1996). Lagurid molars with a "praepannonicus" morphology (broadly confluent triangles T4-T5) prevail in earlier faunas. The mean value of the ratio of anteroconid complex length to the total length of the first lower molar from Nogaisk equals 47.7, which suggests an older age than e.g. Zapadnye Kairy (mean value of this index for $\mathrm{m} 1$ of Prolagurus is 50.0) (Rekovets 1994; Kolfschoten and Markova 2005). The Nogaisk micromammal assemblage is characterised by the appearance of Prolagurus pannonicus and progressiveness of Allophaiomys pliocaenicus, which is recorded in the change of molar morpho structure pattern. The main indexes of this evolutional level are as follows: anteroconid complex to the total tooth length is $42-44$, and the SDQ (Schmelzband-Differenzierung-Quotient, molar enamel thickness) is $90-100$. The evolutionary stage of Prolagurus pannonicus resembles forms from the Tamanian faunal assemblage. Primitive morphotypes of Mimomys also indicate the similar age (Velichko et al. 2010). Based on all these data, the fauna from Nogaisk is dated to the late Early Pleistocene, between ca. 1.2-1.1 Ma. It is correlated with an early Tamanian faunal complex (Iosifova and Agadjanian 2010; Krokhmal 2010; Velichko et al. 2010; Kovalchuk 2017).

\section{Material and methods}

The identification of $P$. brevirostris was performed using basic morphometric analysis. Measurements were taken point to point, with an electronic calliper to the nearest $0.1 \mathrm{~mm}$. Each value given here is the mean of three measurements (all in $\mathrm{mm}$ ). The mean is rounded to one decimal digit. Measuring schemes and morphological terminology were taken and modified from Barycka (2008). Throughout the text, upper teeth are referred to using capital letters (e.g. P4), and lower teeth with lowercase letters (e.g. p4).

The material comprises a few skull fragments of a very large hyena, and all listed remains belong to a single adult individual with slightly worn teeth (Fig. 1). The specimen NMNHU-P 27-1689 is a fragmentary right half of the skull, including a part of the maxilla with I2 and P2-M1, zygomatic arch, palatine and broken basicranium. It is stored in the collection of the Department of Vertebrate Palaeontology (National Museum of Natural History, National Academy of Sciences of Ukraine). The second skull fragment is in the collection of Zaporizhzhia Regional Local History Museum under collection no. P-446/KV-23356. It is the right premaxilla with alveoli of $\mathrm{I} 1$ and $\mathrm{I} 3$ and including $\mathrm{P} 2$ and a part of maxilla with alveoli of P1-P2.
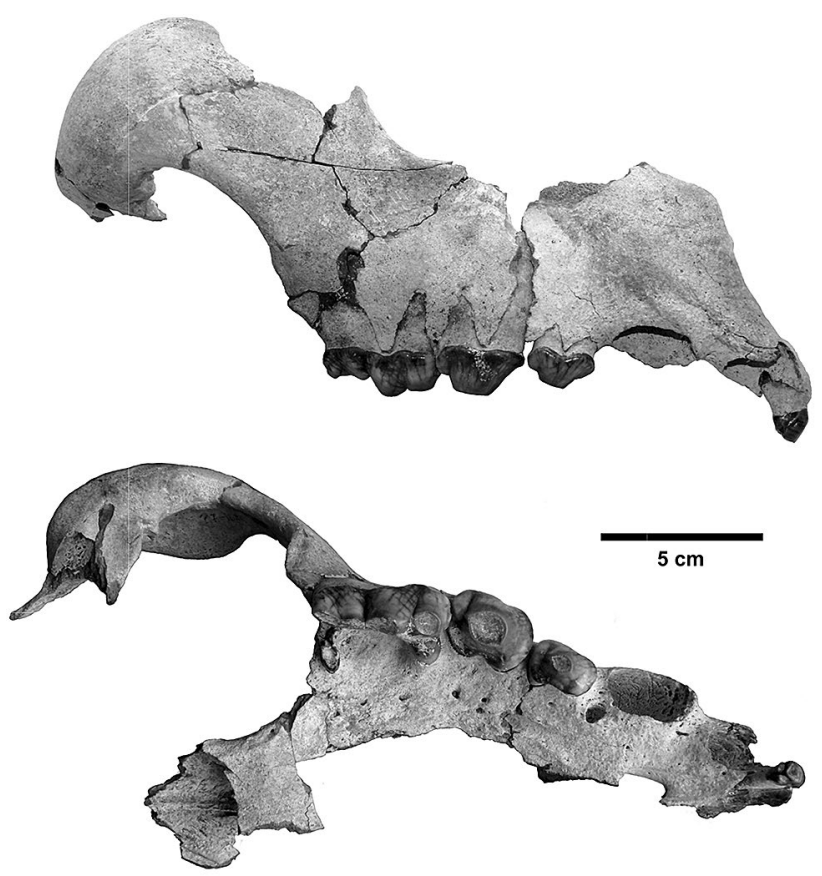

Fig. 1 Cranial fragment of Pachycrocuta brevirostris from Nogaisk (Ukraine) NMNHU-P 27-1689 in buccal view (top) and occlusal view (bottom, scale bar $5 \mathrm{~cm}$ ). Photo by Y. Semenov 


\section{Systematic palaeontology}

\subsection{Description}

The studied skull was previously classified as Hyaena sp. (Topachevsky 1965). The palatine fissure is placed approximately at an angle of $17^{\circ}$ to the sagittal line of the skull (Fig. 1). The major palatine foramen is located in the middle part of maxillary palatine process, at the level of the P3 anterior root. The anterior border of the incisura palatine posterior is placed $23 \mathrm{~mm}$ behind the line connecting the caudal ends of $\mathrm{P} 4$. The length from prosthion to posterior border of hard palate is $173 \mathrm{~mm}$, width at the canines is ca. $80 \mathrm{~mm}$, and ca. $150 \mathrm{~mm}$ between the labial surfaces of P4. The zygomatic arch is very robust: the depth of the zygomatic bone anterior to its frontal process is $50 \mathrm{~mm}$, while the maximum depth of the zygomatic process of the temporal bone is $58 \mathrm{~mm}$. The tube of the external auditory meatus is moderately long and pressed closely against the caudal surface of the postglenoid process.

The tooth row is moderately curved, and the incisors are separated from the canine by a relatively long diastema. Shorter diastemas are present between $\mathrm{C} 1$ and $\mathrm{P} 1$ and $\mathrm{P} 1$ and $\mathrm{P} 2$, while $\mathrm{P} 2-\mathrm{M} 1$ are tightly appressed. All teeth are large and moderately worn (Fig. 1, Table 1). The I1 alveolus is large and narrow, and strongly flattened laterally. The preserved I 2 is a large, strongly laterally flattened tooth, with a strong main cusp with its tip directed distally. Distal to the main cusp, on the distal edge, two smaller, symmetrically positioned cusplets are present. Wear produces an even plane across the apex. Judging from the I3 alveolus, this incisor was canine-like and much larger than the other two incisors. The oval shape of the alveolus shows that $\mathrm{C} 1$ was very large, massive and appreciably flattened. The oval P1 alveolus shows a small, reduced tooth, shifted medially in the tooth row. The two-rooted and rectangular P2 is a broad and low crowned tooth, with relatively short and low main cusp (paracone). The mesial and distal margins of the crown are blunt, while the buccal and lingual margins are more or less straight, and slightly curved only

Table 1 Measurements of Pachycrocuta brevirostris from Nogaisk (all in $\mathrm{mm}$ )

\begin{tabular}{lllll}
\hline Character & P2 & P3 & P4 & M1 \\
\hline Total length & 21.0 & 27.3 & 40.8 & 6.2 \\
Paracone length & 12.5 & 18.2 & 12.3 & \\
Metastyle length & & & 14.4 & \\
Anterior breadth & 12.9 & 19.3 & 24.0 & \\
Posterior breadth & 14.0 & 19.7 & 13.2 & \\
Total breadth & & & & 13.9 \\
\hline
\end{tabular}

in the distal part. Only a delicate concavity of the buccal and lingual sides occurs in the middle part of the crown, in the transition between the mesial and distal portions of the tooth; the transition is slightly marked. The small and low anterior accessory cusplet, the protocone, is shifted moderately mesio-lingually, and weakly associated with the main cusp. It is separated from the paracone by a deep, narrow, $\mathrm{V}$-shaped valley. After the paracone, the posterior accessory cusplet, the hypocone, is placed almost at the midline of the tooth. It is larger than the protocone, but also low and separated from the paracone by a shallow and wide valley. The crocutoid P3 is a massive and moderately high, almost rectangular tooth. It possesses a short and high paracone, which occupies $2 / 3$ the crown length. The mesial, distal and lingual margins of the crown are rounded, while the buccal margin is mostly straight. There are notable concavities in the median part of the crown, in the well-marked transition between the anterior and posterior parts of the tooth. A rudimentary, vestigial anterior cusplet, the protocone, is shifted mesio-lingually. A thin but well-defined ridge runs from its base to the apex of the paracone. The posterior accessory cusplet, the hypocone, is located just behind the main cusp; it is larger than the protocone, and differentiated from the paracone by a deep and V-shaped valley. A crescent-like, shallow, U-shaped valley is present in the disto-lingual part of the crown, between the paracone and the cingulum ridge. A posterior ridge, connecting the hypocone with the apex of the paracone, is sharply pointed and less visible than the anterior ridge. The entire crown is collared by a thick cingulum, which is weakly developed on the buccal side. There is a wide, shallow, U-shaped valley between the cingulum ridge and the paracone on the bucco-mesial and mesial side; it forms a large crescent in occlusal view.

The P4 has a triangular, moderately-developed, relatively narrow and low protocone with centrally positioned tip. Its mesial margin is rounded, and the cusp is situated at an angle of $80^{\circ}$ to the rest of the tooth, and is somewhat forwardly sloped. In occlusal view, the tooth is elongated and narrow, with a convex buccal margin and abruptly ending crown narrowing distally. In buccal view, the tooth looks low. The parastyle is large, high and oval. It is well separated from the paracone by a deep and sharply pointed notch, and the constriction between the parastyle and the paracone is noticeable in occlusal view. The anterior wall of the parastyle bears a small but well-defined preparastyle, which forms a vertical ridge on the mesial side, and is connected with an anterior cingulum. The paracone is relatively low and short, while the metastyle is longer than the paracone. Paracone and metastyle form almost continuous cutting surface; there is only a shallow notch between them. The tooth displays a basal triangle where the strong mesialo-lingual keel joins the cingulum. Perpendicularly oriented to the rest teeth, tworooted M1 is functionally retained and moderately reduced. 
Its oval trigon is collared with a high and thin cingulum wall, and the trigon base is developed into a broad and shallow surface. The talon is more reduced and narrower, and connected with the $\mathrm{P} 4$ metastyle.

\subsection{Comparisons}

The above described, partially preserved skull belonged to a very large hyena, and its fragmentary condition made taxonomic attribution difficult. However, thanks to mainly complete tooth row and moderately worn teeth, it is possible to provide a clear taxonomic affiliation. From this time interval (late Early Pleistocene) in Eastern Europe, the presence of three large hyenas should be taken acknowledged: Pachycrocuta brevirostris, Pliocrocuta perrieri (Croizet and Jobert 1828), and possibly Crocuta crocuta ssp. Perhaps, a fourth, large hyena species, Chasmaporthetes lunensis Del Campana 1914 was present there. However, C. lunensis vanished much earlier, with its last Eurasian appearance documented from the German site Schernfeld dated to 1.8-1.6 Ma (Qiu 1987; Turner et al. 2008; A.M. pers. obs.). In addition, the teeth of this species are distinctly smaller and narrower than those in the specimen from Nogaisk. As for P. perrieri, the examined individual from Nogaisk also cannot be attributed to this species. The size of Nogaisk hyena exceeds the values known for $P$. perrieri, where P3 length does not reach $26.0 \mathrm{~mm}$, and P4 length does not exceed $38.0 \mathrm{~mm}$ (Schütt 1972; Kurtén 1972; Kurtén and Poulianos 1977, 1981).

Only a hypothetical presence of $C$. crocuta in Nogaisk could be proposed, even if this species appeared in European faunas much later, ca. 0.8 Ma in Trinchera Dolina (MadurellMalapeira et al. 2014). P. brevirostris is regarded as the largest hyena ever existed, approaching the size of a female lion, Panthera leo (Linnaeus 1758), with an average weight of ca. $110-120 \mathrm{~kg}$, and the maximal weight up to $180 \mathrm{~kg}$ (Turner and Antón 1996; Turner 2001; Palmqvist et al. 2011). This is twice the weight of the extant spotted hyena, and much larger than the Middle and Late Pleistocene Crocuta crocuta spelaea Goldfuss, 1823. Large teeth were often regarded in the past as a diagnostic feature of the large body size. However, contrary to the canines or the first lower molar (m1), the upper carnassials (P4) are not useful for determining the sexual dimorphism or body size. Their measurements are not correlated with those of the body. As remarked by Lundholm (1952): “...the animal may have been comparatively small, as compared with other members of the same population, however small individuals have had relatively bigger teeth than those in larger specimens". Other possibly important factors that may affect the size of the teeth are climatic and geographical factors, sexual dimorphism and changes over time, which further complicates the interpretation of such data. Contrary to Ursidae, Felidae, and Mustelidae, and partially similarly to Canidae, Hyaenidae are virtually monomorphic in linear measurements, and sexual dimorphism can be cautiously rejected. Comparison of large subspecies of the cave hyena Crocuta crocuta praespelaea with $P$. brevirostris reveals that the latter possesses in average a larger and narrower $\mathrm{P} 4$ with proportionally short metastyle. Beside the size, the present teeth differ also in various diagnostic characters such as a relatively low P3 crown (more brachydont) with stronger hypocone and the development of a triangular surface between the paracone and the strong cingulum ridge on the medio-lingual side. The main cusp is proportionally shorter and lower. The $\mathrm{P} 4$ of the Nogaisk hyena differs from P4 of $C$. crocuta in the presence of well-developed preparastyle, larger parastyle, which is better separated from the paracone, broader blade and proportionally shorter metastyle. Less reduced M1, with a size (13.9 $\mathrm{mm}$ ) exceeding for $C$. crocuta, in which this tooth is rarely larger than $8 \mathrm{~mm}$. The $\mathrm{C} 1$ alveolus is still informative even if the tooth is missing. Its length $(25.4 \mathrm{~mm})$ and width (16.1) exceed the diameters obtained for the very large Middle Pleistocene cave hyenas from Mosbach 2 or Petralona cave (Schütt 1971; Kurtén 1972; Kurtén and Poulianos 1977, 1981). For these reasons, we attribute the analysed specimen from Nogaisk to $P$. brevirostris.

\section{Discussion}

Pachycrocuta brevirostris is first recorded in South Turkwel (northern Kenya, Africa) ca. 3.6-3.5 Ma (Werdelin 1999; Werdelin and Lewis 2000, 2005, 2008), Laetoli ca. 3.5 Ma (Leakey and Hay 1979; Arribas and Palmqvist 1999), West Turkana sites LO5 and LO10 (3.5-3 Ma), possibly Koobi Fora, Tulku Bor Mb (3.4-2.6 Ma). This species was also recorded in Makapansgat (ca. 3.1-3.0 Ma; Howell and petter 1979, 1980; Randall 1981; Arribas and Palmqvist 1998, 1999). The earliest Asian record from Nihowan is slightly younger and dated to ca. 2.0 Ma (Teilhard de Chardin and Piveteau 1930).

Their ancestors likely evolved from the late Miocene Hyaenictitherium (Howell and Petter 1980). P. brevirostris coexisted with Crocuta in Africa during more than 1 million years, and disappeared in East Africa in the Late Pliocene but dispersed and was still present in Southern Africa (Toerien 1952; Randall 1981; Werdelin 1999), where it was recorded among others in Sterkfontein 4-5 (2.6-2.4 Ma; Howell and Petter 1980; Turner 1987; Turner and Antón 1996), Bolt's Farm (2.5-2.3 Ma; Mutter et al. 2001). P. brevirostris is still present in southern Africa during the middle and late Early Pleistocene, and their remains were found in Kromdraai A (1.6-1.5 Ma; Ewer 1954; Howell and Petter 1980; Turner 1987) and Swartkrans 3 (1.5-1.4 Ma; Mutter et al. 2001). The latest African record of the species is 
known from the Gladysvale cave (1.1-1.0 Ma; Mutter et al. 2001).

The Early Pleistocene records of this hyena from Central and Eastern Asia are common: (1) Pinjor Formation (2.5-2.4 Ma; Arribas and Palmqvist 1999); (2) Mohui (2.5-2.4 Ma; Louys 2014); (3) Djetis (2.0-1.9 Ma; Dubois 1908; Schütt 1972; Geraads 1979); (4) Tologoi (2.0-1.8 Ma; Turner and Antón 1996); (5) Volga river (2.0-1.5 Ma; Turner and Antón 1996); (6) Kopaly (1.6-1.5 Ma; Kojamkulova et al. 1987; Sotnikova et al. 1997; Vislobokova 2005); (7) Liucheng (1.2-1.0 Ma; Louys 2014); (8) Zasukhino (1.1-1.0 Ma; Sotnikova 1989; Turner and Antón 1996); (9) Gongwangling (1.1-1.0 Ma; Louys 2014); (10) Lakhuti (1.1-1.0 Ma; Sotnikova and Vislobokova 1990; Turner and Antón 1996); (11) Nalaikcha (1.1-1.0 Ma; Sotnikova 1989; Turner and Antón 1996). P. brevirostris has become quite rare in Asia already in the early Middle Pleistocene and present only in the south-eastern and eastern parts of the continent, being recorded for this period from Bukuran, Ngebung level B and Kedung Brubus, all dated on 0.9-0.8 Ma (Bouteaux et al. 2007; Bouteaux and Moigne 2010; Louys 2014). The species survived during the late Middle Pleistocene, with the latest occurrence at Zhoukoudian 1, dated on 0.5-0.4 Ma (Turner and Antón 1996; Boaz et al. 2000, 2004; Dennell et al. 2008).

During the Early Pleistocene, the species reached Europe (most probably from Asia) (Werdelin 1999; Palmqvist et al. 2011). In a short time, $P$. brevirostris replaced two other large hyaenid species, the large bone-crushing Pliocrocuta perrieri and the gracile pack hunter Chasmaporthetes lunensis (Turner and Antón 1996; Turner et al. 2008). It was present in Europe between 2.0 and $0.7 \mathrm{Ma}$, and finally disappeared during the early Middle Pleistocene (Fig. 2; Table 2; Turner and Antón 1996; Arribas and Palmqvist 1999; Turner et al. 2008; Palmqvist et al. 2011).
The extinction of $P$. brevirostris in Europe was probably linked to the decline and subsequent extinction of sabertooth cats, particularly Megantereon whitei and Homotherium crenatidens (Martínez-Navarro and Palmqvist 1996; Palmqvist et al. 1996a, b; Palmqvist and Arribas 2001a, b; Palmqvist et al. 2011). Disappearance of these cats implied the loss of an important source of partly consumed carcasses and thus a change in the interactions between flesh-eating and bone-crushing species of the carnivore guild.

$P$. brevirostris was a member of the large carnivore paleoguild comprising also Lycaon falconeri/lycaonoides, Canis etruscus/mosbachensis, Ursus etruscus/arctos, $H$. crenatidens/latidens, M. whitei, Panthera toscanalgombaszoegensis, Acinonyx pardinensis, Puma pardoides, and Lynx issiodorensis/pardinus. This carnivore assemblage existed in Eurasia for more than one million years (between 2.0 and $0.9-0.8 \mathrm{Ma}$ ), and its paleohierarchy was more or less stable. Thanks to its large size and social lifestyle, $P$. brevirostris was one of the dominant species (Turner and Antón 1996; Turner 2001; Palmqvist et al. 2011).

Nevertheless, the evolutionary history of this species was ended during the latest Early Pleistocene, where $P$. brevirostris was replaced by $C$. crocuta. The earliest European records of this species are known from Spanish sites at the Gran Dolina of Atapuerca (García 2003). In general opinion, Trinchera Dolina 4 (TD4) is dated to the EarlyMiddle Pleistocene boundary (ca. $0.78 \mathrm{Ma}$ ). However, new ESR dates suggest that the age of this horizon is closer to $0.9 \mathrm{Ma}$, whereas Trinchera Dolina 4 (TD4) is close to the Jaramillo subchron (Moreno-García 2011; Madurell-Malapeira et al. 2014). This new chronological background suggests co-existence in time of $P$. brevirostris and $C$. crocuta in the Iberian Peninsula during the latest Early Pleistocene
Fig. 2 Distribution of PlioPleistocene sites with P. brevirostris in Europe and adjoining areas. For locality numbers see Table 2




Table 2 Occurrence of P. brevirostris in the Plio-Pleistocene of Europe and adjoining areas. Locality numbers (Map) correspond to those in Fig. 2

\begin{tabular}{|c|c|c|c|}
\hline Map & Site & Age (in Ma) & Literature \\
\hline 1 & Almenara-Casablanca 1 & $2.0-1.8$ & Soto and Morales 1985; Agusti and Moyà Solà 1998; Madurell-Malapeira et al. 2014 \\
\hline 2 & Coste San Giacomo & $2.2-2.0$ & Biddittu et al. 1979; Bellucci et al. 2012 \\
\hline 3 & Beremend 15 & $2.6-2.4$ & Jánossy 1987 \\
\hline 4 & Yassioren & $2.4-2.2$ & Ozansoy 1965 \\
\hline 5 & Cassa Frata & $1.9-1.8$ & $\begin{array}{l}\text { Borselli et al. 1980; De Giuli and Masini 1986; Caloi and Palombo 1995; Turner et al. } \\
2008\end{array}$ \\
\hline 5 & Casa Sgherri (Massarella) & $1.9-1.8$ & Turner et al. 2008 \\
\hline 6 & Dmanisi & $1.9-1.8$ & Palmqvist et al. 2011 \\
\hline 7 & Gerakarou & $1.9-1.8$ & Kostopoulos et al. 2002; Koufos and Kostopoulos 2016 \\
\hline 8 & Olivola & $1.9-1.8$ & Azzaroli 1977, 1983; Turner et al. 2008 \\
\hline 9 & Poggio Rosso & $1.9-1.8$ & Alberdi et al. 1998; Mazza et al. 2004 \\
\hline 10 & Tasso & $1.9-1.8$ & Alberdi et al. 1998 \\
\hline 5 & Upper Valdarno & $1.9-1.8$ & $\begin{array}{l}\text { Del Campana 1914; Bonifay 1971; Azzaroli et al. 1988; Torre et al. 1993; Rook et al. } \\
2013\end{array}$ \\
\hline 11 & Val di Magra & $1.9-1.8$ & Forsyth Major 1890; Gliozzi et al. 1997 \\
\hline 12 & Villa Spinola & $1.9-1.8$ & Tuccimei 1896; Bortolotti 1903 1905; Argenti 2004 \\
\hline 13 & Kisláng & $1.9-1.7$ & Kretzoi 1954; Jánossy 1986; Turner and Antón 1996 \\
\hline 14 & Cava est Casigliano & $1.8-1.7$ & Argenti 2004 \\
\hline 15 & Casale Violino & $1.8-1.7$ & Ambrosetti et al. 1995; Argenti 2004 \\
\hline 16 & Fonelas P-1 & $1.8-1.7$ & Garrido 2006; Viseras et al. 2006; Arribas and Garrido 2008; Arribas et al. 2009 \\
\hline 17 & Fontana Acetosa & $1.8-1.7$ & Caloi and Palombo 1995; Kahlke et al. 2011 \\
\hline 18 & Colle Saint Andrea & $1.8-1.7$ & Argenti 2004 \\
\hline 19 & Trlica & $1.8-1.6$ & Dimitrijević 1990; Dimitrijević et al. 2006; Vislobokova and Agadjanian 2015 \\
\hline 20 & Hérault & $1.6-1.5$ & Crochet et al. 2009 \\
\hline 21 & Livakkos & $1.6-1.5$ & Steensma 1988; Koufos and Kostopoulos 1997; Koufos 2014 \\
\hline 22 & Monte Argentario & $1.6-1.5$ & Baschieri and Serge 1957 \\
\hline 23 & Venta Micena & $1.6-1.5$ & $\begin{array}{l}\text { Pons-Moyà 1987; Martínez-Navarro 1992; Palmqvist et al. 1996a, b, 2003, 2005, 2011; } \\
\text { Medin et al. } 2017\end{array}$ \\
\hline 15 & Leffe Basin & $1.6-1.4$ & Breda and Marchetti 2007 \\
\hline 24 & Paciano & $1.6-1.4$ & Argenti 2004 \\
\hline 23 & Barranco León 5 & $1.5-1.4$ & Turq et al. 1996; Martínez-Navarro et al. 2003, 2004, 2010 \\
\hline 25 & Westbury-sub-Mendip & $1.5-1.4$ & Bishop 1982, Turner 1995, 1999, 2009 \\
\hline 26 & Tsiotra Vryssi & $1.5-1.3$ & Konidaris et al. 2015 \\
\hline 27 & Sartanette & $1.5-1.3$ & Bonnet 1980, Palombo and Valli 2004 \\
\hline 28 & Escoffier & $1.5-1.1$ & Fourvel and Lateur 2016 \\
\hline 23 & Fuente Nueva 3 & $1.4-1.3$ & Turq et al. 1996; Martínez-Navarro et al. 2003, 2010; Espigares et al. 2013; \\
\hline 7 & Kalamoto & $1.4-1.3$ & Tsoukala and Chatzopoulou 2005; Konidaris et al. 2015 \\
\hline 7 & Apollonia 1 & $1.3-1.2$ & Koufos and Kostopoulos 1997; Koufos 2018 \\
\hline 29 & Ceyssaguet & $1.3-1.2$ & Tsoukala and Bonifay 2004; Argant and Bonifay 2011 \\
\hline 30 & Nogaisk & $1.3-1.2$ & Topachevsky 1965 \\
\hline 31 & Pirro Nord & $1.3-1.2$ & De Giuli et al. 1986; Turner et al. 2008; Petrucci et al. 2013 \\
\hline 20 & Bois-de-Riquet & $1.3-1.1$ & Crochet et al. 2009; Bourguignon et al. 2016 \\
\hline 27 & Grosse Marguerite cave & $1.3-1.1$ & Fourvel and Lateur 2016 \\
\hline 32 & Trois Pigeons & $1.3-1.1$ & Fourvel and Lateur 2016 \\
\hline 33 & Saint-Prest & $1.2-1.0$ & Guérin 1980; Guérin et al. 2003; Palombo and Valli 2004; Guérin 2007 \\
\hline 34 & Pontón de la Oliva & $1.1-1.0$ & Cabra et al. 1983; Sesé and Ruiz-Bustos 1992; Madurell-Malapeira et al. 2014 \\
\hline 35 & Promano & $1.1-1.0$ & Argenti 2004 \\
\hline 36 & Sainzelles & $1.1-1.0$ & Aymard 1846; Boule 1893; Guérin 1980, Alba et al. 2015 \\
\hline 37 & Akhakalaki 1 & $1.1-1.0$ & Martinez-Navarro et al. 2009 \\
\hline
\end{tabular}


Table 2 (continued)

\begin{tabular}{|c|c|c|c|}
\hline Map & Site & Age (in Ma) & Literature \\
\hline 38 & Cueva Victoria & $1.1-0.8$ & $\begin{array}{l}\text { Pons-Moyà and Moyà-Solà 1978; Agustí et al. 1986; Aguirre 1989; Madurell-Malapeira } \\
\text { et al. } 2015\end{array}$ \\
\hline 39 & Liventsovka & $1.1-1.0$ & Sotnikova et al. 2002; Titov 2008; Sotnikova and Titov 2009 \\
\hline 40 & Vallonnet cave & $1.1-1.0$ & de Lumley et al. 1988; Moullé 1992, 1998; Moullé and Tréguier 2006 \\
\hline 41 & Untermassfeld & $1.1-1.0$ & Kahlke 2000; Turner 2001; Kahlke and Gaudzinski 2005 \\
\hline 42 & Akhtanizovskaya & $1.1-0.9$ & Sotnikova and Titov 2009 \\
\hline 43 & Cal Guardiola Lower Unit & $1.2-1.1$ & Madurell-Malapeira et al. 2009a, 2009b, 2010, 2014 \\
\hline 44 & Incarcal & $0.9-0.8$ & Galobart et al. 2003 \\
\hline 43 & Vallparadís Estació Lower Unit & $1.0-0.9$ & Madurell-Malapeira et al. 2009a, 2009b, 2010, 2014, 2015, 2017 \\
\hline 43 & Cal Guardiola Upper Unit & $0.9-0.8$ & Madurell-Malapeira et al. 2009a, 2009b, 2010, 2014, 2015, 2017 \\
\hline 45 & Prezletice & $0.9-0.8$ & Fejfar 1995; Koenigswald and Heinrich 1999 \\
\hline 46 & Chlum 1 & $0.8-0.7$ & Beneš 1970; Horáček et al. 2016 \\
\hline 46 & Chlum 4 & $0.8-0.7$ & Beneš 1970; Horáček et al. 2016 \\
\hline 47 & Slivia & $1.0-0.9$ & Ambrosetti et al. 1979, 1995; Turner and Antón 1996; Caloi and Palombo 1995 \\
\hline 43 & Vallparadís Estació Middle Unit & $0.85-0.8$ & Madurell-Malapeira et al. 2009a, 2009b, 2010, 2014, 2015, 2017 \\
\hline 48 & Bacton & $0.8-0.7$ & Bishop 1982; Lewis et al. 2010 \\
\hline 48 & Forest Bed & $0.8-0.7$ & Lewis et al. 2010 \\
\hline 45 & Koneprusy C718 & $0.8-0.7$ & Turner and Antón 1996 \\
\hline 49 & Manastirec & $0.8-0.7$ & Kurtén and Garevski 1989 \\
\hline 48 & Mundesley & $0.8-0.7$ & Bishop 1982; Turner 1995, 1999 \\
\hline 50 & Petralona cave & $0.8-0.7$ & Kurtén and Poulianos 1977, 1981; Baryshnikov and Tsoukala 2010 \\
\hline 48 & Overstrand & $0.8-0.7$ & Lewis et al. 2010 \\
\hline 48 & Sidestrand & $0.8-0.7$ & Freudenberg 1914; Bishop 1982; Lewis et al. 2010 \\
\hline 45 & Stránská skála & $0.8-0.7$ & Stehlík 1934; Kurtén 1968, 1972; Musil 1995 \\
\hline 51 & Tiraspol & $0.8-0.7$ & Pavlow 1925; Nikivorova et al. 1971; Godina and David 1973 \\
\hline 52 & Würzburg-Schalksberg & $0.8-0.7$ & Schütt 1974; Mäuser 1987; Turner et al. 2008 \\
\hline 49 & West Runton & $0.75-0.7$ & Turner 2009; Lewis et al. 2010; Stuart and Lister 2010 \\
\hline 53 & Süssenborn & $0.8-0.7$ & Soergel 1936; Kahlke 1961; Schaefer 1969 \\
\hline 54 & Gombaszög & $0.8-0.7$ & Kretzoi 1938, 1941 \\
\hline 55 & Brown Ridge & ? & Erdbrink and van Bree 1995 \\
\hline
\end{tabular}

(Madurell-Malapeira et al. 2014). This should not be surprising, since the co-existence of these two hyaenids is well documented for more than one million years in East Africa (Werdelin and Lewis 2005). Although it should be noted that the African $C$. crocuta that co-existed with $P$. brevirostris was a much smaller and gracile species than the European Middle Pleistocene form (Madurell-Malapeira et al. 2014).

It is interesting that $P$. brevirostris disappeared more or less simultaneously in most of Europe, and survived only in Western and Central Europe (Turner and Antón 1996; Turner 2001; Palmqvist et al. 2011). But even there sites younger than $0.7 \mathrm{Ma}$ are unknown. The only exception is the Hungarian site Vertesszöllös 2, but the presence of this species is based on questionable remains (Jánossy 1990). Also, some admixture of older layers also cannot be excluded
(Burdukiewicz pers. comm.). Numerous species, like $L$. lycaonoides or P. gombaszoegensis, which co-occurred with $P$. brevirostris, survived in Central and Eastern Europe longer, even until the late Middle Pleistocene (MIS 11-10) (Jánossy 1990; Baryshnikov 2011; Marciszak 2014). The exact answer for this difference is unknown and needs further research.

$P$. brevirostris disappeared relatively fast likely due to the competitive pressure from $C$. crocuta, but the exact reconstruction of this scenario is still unresolved. It is known that, despite its larger body size, $P$. brevirostris has proportionally smaller teeth than $C$. crocuta, which was not only better adapted for bone crushing (proportionally wider and larger P3 and p3), but also for slicing the meat. Upper carnassials (P4) of $P$. brevirostris had a proportionally shorter metastyle 
(cutting blade) and narrower crown, while its lower carnassials (m1) were smaller (compared to body size) with shorter major cusps (Turner and Antón 1996; Turner 2001; Barycka 2008). Both species are characterised by other adaptations to bone crushing like zigzag-like enamel structure (Stefen and Resenberger 2002, Barycka 2008). In aggressive encounters one to one, $C$. crocuta had likely no chance against $P$. brevirostris, but $C$. crocuta lived and hunted in larger clans than P. brevirostris (Turner and Antón 1996; Turner 2001; Barycka 2008; Palmqvist et al. 2011). These two reasons, better adaptation for crushing bones and meat slicing and more numerous clans, were probably the main factors responsible for the success of $C$. crocuta. However, other factors might also have played some role in this process. As was pointed by Vinuesa et al. (2016), the ancestral/plesiomorphic condition in bone-crushing hyenas were limited social behavior with putative main scavenger behavior (i.e. similar to extant brown hyenas). The extreme social behavior displayed by the extant spotted hyenas probably was related with unknown selective pressures occurred during the Middle Pleistocene in East Africa or idiosyncratic biological characteristics of this species. Taking this into account, the scenario discussed above showed not to be so clear and still needs further verification (Vinuesa et al. 2016).

The first Ukrainian record described here, dated to 1.3-1.2 Ma, fits well into this scenario. Beside the single record from Ubeidyia, dated to 1.5-1.4 Ma (Martínez-Navarro et al. 2009), there are no other known Eastern European or Western Asian records of $C$. crocuta. In this context, the co-occurrence $P$. brevirostris with $C$. crocuta seems unlikely in this area, but needs further investigation. Specimens of $P$. brevirostris from various earlier sites located in neighbouring areas to the so called "Khapry fauna" of Nogaisk are morphologically similar to the Asian forms. This might indicate that $P$. brevirostris may have appeared in Eastern Europe earlier than in western regions (Sotnikova et al. 2002). In general, the Asian influence on the fauna of the Azov region was reasonably strong. Apart from carnivores, which appeared here earlier than in Western Europe by the invasion from the east, the Khaprovian faunal assemblage consists of typical Asian elements (Sotnikova et al. 2002).

Acknowledgements We are very grateful to Oleksandr Kovalchuk for linguistic improvements and to two anonymous reviewers for their insightful comments and remarks, which significantly improved the manuscript. The research was financed from the subsidies for the activities of the Institute of Environmental Biology, University of Wrocław, no. 2020 (501).

Open Access This article is licensed under a Creative Commons Attribution 4.0 International License, which permits use, sharing, adaptation, distribution and reproduction in any medium or format, as long as you give appropriate credit to the original author(s) and the source, provide a link to the Creative Commons licence, and indicate if changes were made. The images or other third party material in this article are included in the article's Creative Commons licence, unless indicated otherwise in a credit line to the material. If material is not included in the article's Creative Commons licence and your intended use is not permitted by statutory regulation or exceeds the permitted use, you will need to obtain permission directly from the copyright holder. To view a copy of this licence, visit http://creativecommons.org/licenses/by/4.0/.

\section{References}

Aguirre, E. (1989). Vertebrados del Pleistoceno continental. In A. Pérez-González, P. Cabra, \& A. Martin-Serrano (Eds.), Memoria del Mapa del Cuaternario de España (pp. 47-69). Madrid: Instituto Tecnológico Geominero de España.

Agusti, J., \& Moyà Solà, S. (1998). The Early Pleistocene mammal turnover in Spain: evidence against an "End-Villafranchian" event. Mededelingen Nederlands Instituut voor Toegepaste Geowetenschappen TNO, 60, 513-520.

Agustí, J., Moyà-Solà, S., \& Pons-Moyà, J. (1986). Venta Micena (Guadix-Baza basin, south-eastern Spain): its place in the Plio-Pleistocene mammal succession in Europe. Geologica Romana, 25, 33-62.

Alba, D. M., Vinuesa, V., \& Madurell-Malapeira, J. (2015). On the original author and year of description of the extinct hyaenid Pachycrocuta brevirostris. Acta Palaeontologica Polonica, 60(3), 573-576.

Alberdi, M. T., Caloi, L., \& Palombo, R. M. (1998). Large mammal associations from the Early Pleistocene: Italy and Spain. Mededelingen Nederlands Instituut voor Toegepaste Geowetenschappen TNO, 60, 521-532.

Alekseeva, L. I. (1977). Early Anthropogene Theriofauna of Eastern Europe (p. 216). Moscow: Nauka.

Ambrosetti, P., Bartolomei, G., De Giuli, C., Ficcarelli, G., \& Torre, D. (1979). La breccia ossifera di Slivia (Aurisina-Sistiana) nel Carso di Trieste. Bolletino della Società Paleontologica Italiana, 18(2), 207-220.

Ambrosetti, P., Basilici, G., Capasso Barbato, L., Carboni, M. G., Di Stefano, G., Esu, D., et al. (1995). Il Pleistocene inferiore nel ramo sud-occidentale del Bacino Tiberino (Umbria): aspetti litostratigrafici e biostratigrafici. Il Quaternario, 8, 16-36.

Argant, J., \& Bonifay, M.-F. (2011). Les coprolithes de hyène (Pachycrocuta brevirostris) de la couche 2 du site villafranchien de Ceyssaguet (Lavoûte-sur-Loire, Haute-Loire, France): analyse pollinique et indications paléoenvironnementales. Quaternaire, 22(1), 3-11.

Argenti, P. (2004). Plio-Quaternary mammal fossiliferous sites of Umbria (central Italy). Geologica Romana, 37, 67-78.

Arribas, A. Garrido, G., (2008): Hiénidos [Pachycrocuta brevirostris (Aymard, 1846) y Hyaena brunnea Thunberg, 1820] del yacimiento de Fonelas P-1 (Cuenca de Guadix, Granada). In: Arribas A. (Ed.), Vertebrados del Plioceno Superior Terminal en el Suroeste de Europa: Fonelas P-1 y el Proyecto Fonelas. Cuadernos del Museo Geominero 10, 201-230.

Arribas, A., Garrido, G., Viseras, C., Soria, J. M., Pla, S., Solano, J. G., et al. (2009). A mammalian lost world in southwest Europe during the Late Pliocene. PLoS ONE, 4(9), 7127.

Arribas, A., \& Palmqvist, P. (1998). Taphonomy and paleoecology of an assemblage of large mammals: hyaenid activity in the Lower Pleistocene site at Venta Micena (Orce, Guadix-Baza Basin, Granada, Spain). Geobios, 31(3), 3-47.

Arribas, A., \& Palmqvist, P. (1999). On the ecological connection between sabre-tooth and hominids: faunal dispersal events in the Lower Pleistocene and a review of the evidence for the first human arrival in Europe. Journal of Archaeological Science, $26,571-585$. 
Aymard, A. (1846). Communication sur le gisement de Sainzelles. Annales de la Société d'Agriculture, Science et Arts Commerce du Puy, 13, 153-155.

Azzaroli, A. (1977). The Villafranchian stage in Italy and the PlioPleistocene boundary. Giornale di Geologia, 41, 61-79.

Azzaroli, A. (1983). Quaternary mammals and the "End-Villafranchian" dispersal event. A turning point in the history of Eurasia. Palaeogeography, Palaeoclimatology, Palaeoecology, 44, 117-139.

Azzaroli, A., De Giuli, C., Ficcarelli, G., \& Torre, D. (1988). Late Pliocene to early mid- Pleistocene mammals in Eurasia: faunal succession and dispersal events. Palaeogeography, Palaeoclimatology, Palaeoecology, 66, 77-100.

Baigusheva, V. S. (2000). New data on the Tamanian faunistic complex from the excavation near the Semibalki Village (the Sea of Azov coast. Historical and Archaeological Research in Azov and Lower Don in 1998. Azov: Azov Historical. Archaeological and Paleontological Museum Reserve, 16, 27-57.

Baigusheva, V.S., Titov, V.V. (2008): The Taman Faunistic complex of large vertebrates of the Azov and Lower Don regions. In: Early Palaeolithic of Eurasia: new discoveries. Abstracts of the International Conference, Krasnodar, Temryuk, 1-6.09.2008. Southern Scientific Centre Russian Academy of Science, Rostov-on-Don, 123-124.

Barycka, E. (2008). Middle and Late Pleistocene Felidae and Hyaenidae of Poland (p. 228). Warszawa: Fauna Poloniae.

Baryshnikov, G. F. (2011). Pleistocene Felidae (Mammalia, Carnivora) from the Kudaro Palaeolithic cave sites in the Caucasus. Proceedings of the Zoological Institute Russian Academy of Science, 315, 197-226.

Baryshnikov, G. F., \& Tsoukala, E. (2010). New analysis of the Pleistocene carnivores from Petralona Cave (Macedonia, Greece) based on the collection of the Thessaloniki Aristotle University. Geobios, 43, 389-402.

Baschieri, F., \& Serge, A. G. (1957). Notizie sul ritrovamento di fauna a rinoceronte etrusco e macairodo all'Argentario (prov. di Grosseto). Quaternaria, 4, 195-197.

Bellucci, L., Mazzini, I., Scardia, G., Bruni, L., Parenti, F., Segre, A. G., et al. (2012). The site of Coste San Giacomo (Early Pleistocene, central Italy): Palaeoenvironmental analysis and biochronological overview. Quaternary International, 267, 30-39.

Beneš, J. (1970). Pleistocénní savci z Chlumu u Srbska (Čechy). Časopis Národního muzea, Oddíl př́rodovědný, 137(3/4), 17-26.

Biddittu, I., Cassoli, P. F., Radicati di Brozolo, F., Segre, A. G., Segre Naldini, E., \& Villa, I. (1979). Anagni, a K-Ar dated Lower and Middle Pleistocene site, central Italy: preliminary report. Quaternaria, 21, 53-71.

Bishop, M. J. (1982). The mammal fauna of the early middle Pleistocene cavern infill site of Westbury-sub-Mendip, Somerset. Palaeontological Association Special Paper, 28, 1-108.

Boaz, N. T., Ciochon, R. L., Xu, Q., \& Liu, J. (2000). Large mammalian carnivores as a taphonomic factor in the bone accumulation at Zhoukoudian. Acta Anthropologica Sinica, 19, 224-234.

Boaz, N. T., Ciochon, R. L., Xu, Q., \& Liu, J. (2004). Mapping and taphonomic analysis of the Homo erectus loci at Locality 1 Zhoukoudian, China. Journal of Human Evolution, 46, 519-549.

Bonifay, M.-F. (1971). Carnivores quaternaires du sud-est de la France. Mémoires du Muséum National d'Histoire Naturelle, Série C, 21(2), 1-377.

Bonnet, A. (1980). Le gisement à faune à Machairodus de la Sartanette (Remoulins, Gard); Nouveau repère biostratigraphique antémindelien. Supplément au Bulletin de l'Association Française pour l'Étude du Quaternaire, 1980, 348-350.

Borselli, V., De Giuli, C., Ficcarelli, G., \& Mazzini, M. (1980). Casa Frata: una località fossilifera del Villafranchiano Superiore presso Terranuova Bracciolini (Arezzo) nel Valdarno Superiore. Bolletino della Società Paleontologica Italiana, 19(2), 245-258.

Bortolotti, C. (1903). Intorno ad alcuni resti di rinoceronte nei dintorni di Perugia. Rivista Paleontologica Italiana, 9, 50-53.

Bortolotti, C. (1905). Intorno ad un resto di mandibola di iena. Rivista Paleontologica Italiana, 11, 34-36.

Boule, M. (1893). Description de l'Hyaena brevirostris du Pliocène de Sainzelles près de Le Puy (Haute-Loire). Annales des Sciences Naturelles, 8(15), 85-97.

Bourguignon, L., Crochet, J.-Y., Capdevila, R., Ivorra, J., Antoine, P.-O., Agustí, J., et al. (2016). Bois-de-Riquet (Lézignan-laCèbe, Hérault): A late Early Pleistocene archeological occurrence in southern France. Quaternary International, 393, 24-40.

Bouteaux, A., Moigne, A.-M., Sémah, F., \& Jacob, T. (2007). Les assemblages fauniques associés aux sites à Homo erectus du dôme de Sangiran (Pléistocène moyen, Java, Indonésie). Comptes Rendus Paléovol, 6(3), 169-179.

Bouteaux, A., \& Moigne, A.-M. (2010). New taphonomic approaches: the Javanese Pleistocene open-air sites (Sangiran, central Java). Quaternary International, 223-224, 220-225.

Breda, M., \& Marchetti, M. (2007). Pleistocene mammal faunas from the Leffe Basin (Bergamo, Northern Italy): revision and new data. Courier Forschungsinstitut Senckenberg, 259, 61-77.

Bukhsianidze, M., Chagelishvili, R., Hertler, C., Kvavadze, E., Martkoplishvili, I. (2014): New findings about the Akhalkalaki site (Southern Georgia, Caucasus; 0.98-0.78 Ma). In: Kostopoulos, D.S., Vlachos, E., Tsoukala, E. (Eds.), Abstracts of the 6th International Conference on mammoths and their relatives. Scientific Annals, School of Geology, Aristotle University, Thessaloniki 102,38 .

Cabra, P., Goy, J. L., Hoyos, M., \& Zazo, C. (1983). Estudio geomorfológico del Cuaternario y de las formaciones superficiales del sector meridional de la Sierra de Cabrera. Tecniterrae, 51, 32-42.

Caloi, L., \& Palombo, M. R. (1995). Le mammalofaune del Pleistocene inferior nell'Italia centrale. Biostratigrafia dell'Italia centrale, 1994, 487-501.

Crochet, J.-Y., Welcomme, J.-L., Ivorra, J., Ruffet, G., Boulbes, N., Capdevila, R., et al. (2009). Une nouvelle faune de vertébrés continentaux, associée à des artifacts dans le Pléistocène inférieur de l'Hérault (Sud de la France), ver 1,57 Ma. Comptes Rendus Palevol, 8(8), 725-736.

Del Campana, D. (1914). La Lycyaena lunensis n. sp. dell'ossario pliocenico di Olivola (Val di Magra). Paleontographia Italica, 20, $87-104$

Dennell, E. W., Coard, R., \& Turner, A. (2008). Predators and scavengers in Early Pleistocene southern Asia. Quaternary International, 192, 78-88.

De Giuli, C., \& Masini, F. (1986). Late Villafranchian faunas in Italy: the Casa Frata local fauna (Upper Valdarno, Tuscany). Palaeontographia Italica, 74, 1-9.

De Giuli, C., Masini, F., \& Torre, D. (1986). The latest Villafranchian faunas in Italy: the Pirro Nord fauna (Apricena, Gargano). Palaeontographia Italica, 74, 51-62.

Dimitrijević, V. (1990). Prvi rezultati istrazivanja sisarske faune iz Trlice kod Pljevlja. Zbornik radova XII XII Kongres na geolozi na Jugoslavija, 1, 328-336.

Dimitrijević, V., Zic, J., \& Mijovic, D. (2006). Pleistocene fauna on Trlica near Pljevlja (Montenegro). Revue de Paléontologie, 2(6), $6-7$.

Dodonov, A. E., Zhou, L. P., Markova, A. K., Tchepalyga, A. L., Trubikhin, V. M., Aleksandrovski, A. L., \& Simakova, A. N. (2006). Middle-Upper Pleistocene bio-climatic and magnetic records of the Northern Black Sea coastal area. Quaternary International, $149,44-54$ 
Dubois, E. (1908). Das geologische Alter der Kendeng-oder Trinilfauna. Tijdschrift van het Koninklijk Nederlandsch Aardrijkskundig Genootschap, 25, 1235-1270.

Dubrovo, I. A. (1963). New evidence on the Tamanian faunal complex of vertebrates. Bulletin of the Moscow Society of Naturalists, Geological Series, 38(6), 94-99.

Dubrovo, I. A., \& Alekseev, M. N. (1964). To the stratigraphy of the Quaternary sediments of the Sea of Azov. Bulletin of the Commission for Study of the Quaternary, 29, 35-43.

Dubrovo, I. A., \& Kapelist, K. V. (1979). Catalogue of localities of Tertiary vertebrates in the USSR (p. 158). Moscow: Nauka Press.

Erdbrink, D. P. B., \& van Bree, P. J. H. (1995). Hyaena brevirostris, a curious fragment from the bottom of the North Sea. Beaufortia, 45(7), 105-114.

Espigares, M. P., Martínez-Navarro, B., Palmqvist, P., Ros-Montoya, S., Toro, I., Agustí, J., \& Sala, R. (2013). Homo vs. Pachycrocuta: Earliest evidence of competition for an elephant carcass between scavengers at Fuente Nueva-3 (Orce, Spain). Quaternary International, 295, 113-125.

Ewer, R. F. (1954). The Hyaenidae of Kromdraai. Proceedings of the Zoological Society of London, 124(3), 565-585.

Fejfar, O. (1995). Die Fauna aus den limnischen Ablagerungen von Přezletice bei Prag und ihre biochronologische Aussage. Jahrbuch des Römisch-Germanischen Zentralmuseums Mainz, 40(1), 103-113.

Forsyth Major, C. J. (1890). Note on a Pliocene mammalian fauna at Olivola in the Upper Val di Magra (Prov. Massa-Carrara) Italy. Geological Magazine, 3(7), 305-308.

Fourvel, J.-B., \& Lateur, N. (2016). Note sur deux mandibules de Pachycrocuta brevirostris (Aymard, 1846) du Pléistocène ancien du sud-est de la France: la grotte de la Grosse Marguerite (Aiguèze) et l'aven des Trois Pigeons (Nîmes). Paleo, 26, 187-200.

Freudenberg, W. (1914). Die Säugetiere des älteren Quartärs von Mitteleuropa mit besonderer Berücksichtigung der Fauna von Hundsheim und Deutschaltenburg in Niederösterreich etc. Geologische und Paläontologische Abhandlungen, Neue Folge, 12(4-5), $1-219$.

Galobart, A., Antón, M., \& Maroto, J. (2003). Hienidos y canidos de los yacimientos de Incarcal (Girona, NE de la Peninsula Iberica). Una aproximacion a la paleobiologia del hienido del Pleistoceno inferior. Paleontology and Evolution, 34, 79-98.

García, N. (2003). Osos y otros carnívoros de la Sierra de Atapuerca. Oviedo: Fundación Oso de Asturias.

Garrido, G. (2006): Paleontología sistemática de grandes mamíferos del yacimiento del Villafranquiense superior de Fonelas P-1 (Cuenca de Guadix, Granada). Ph.D. dissertation, Universidad Complutense de Madrid, $726 \mathrm{p}$.

Garutt, V. E. (1954). Southern elephant Archidiskodon meridionalis (Nesti) from the Pliocene of the northern Coast of the Azov Sea. Proceedings of the Commission for Research into the Quaternary Period, 10(2), 1-76.

Garutt, V.E., Foronova, I.V. (1976): Researches on the teeth of fossil elephants. Methodological recommendations. United Institute of Geology, Geophysics and Mineralogy, Siberian Branch of the Russian Academy of Science, Novosibirsk, 36 p.

Garutt, W. E., Gentry, A., \& Lister, A. M. (1990). Mammuthus Brookes, 1828 (Mammalia, Proboscidea): proposed conservation, and Elephas primigenius Blumenbach, 1799 (currently Mammuthus primigenius): proposed designation as the type species of Mammuthus, and designation of a neotype. Bulletin of Zoological Nomenclature, 47, 38-44.

Geraads, D. (1979). Nouvelles donées sur Hyaena brevirostris bathygnatha Dubois (Carnivora, Mammalia) du Pleistocène de Java. Comptes Rendus Sommaires Société Geologique de France, 2, 80-82.
Gliozzi, E., Abbazzi, L., Argenti, P., Azzaroli, A., Caloi, L., Capasso Barbato, L., et al. (1997). Biochronology of selected mammals, molluscs, ostracods from the Middle Pliocene to the Late Pleistocene in Italy. The state of the art. Rivista Italiana di Paleontologia i Stratigrafia, 103(3), 369-388.

Godina, A.J., David, A.I. (1973): Neogenovye mectonakhozhdeniya pozvocznykh na territorii Moldavskoi SSr, Chisinau.

Gromov, V. I. (1948). Paleontological and archaeological foundation of the Quaternary stratigraphy of continental sediments in the USSR. Transactions of the Geological Institute of the Academy of Sciences of the USSR, Series Geology, 64(17), 1-521.

Guérin, C. (1980). Les Rhinocéros (Mammalia, Perissodactyla) du Miocène terminal au Pléistocène Supérieur en Europe Occidentale. Documents des laboratoires de géologie de la Faculté des Sciences de Lyon, 79, 1-1185.

Guérin, C. (2007). Biozonation continentale du Plio-Pléistocène d'Europe et d'Asie occidentale par les mammifères: état de la question et incidence sur les limites tertiaire/quaternaire et PlioPléistocène. Quaternaire, 18(1), 23-33.

Guérin, C., Dewolf, Y., \& Lautridou, J. P. (2003). Révision d'un site paléontologique célèbre: Saint Prest (Chartres, France). Geobios, $36,55-82$.

Horáček, I., Bláha, V., Wagner, J., Čermák, S., Žák, K., \& Ryšánek, K. (2016). Speleologie a výzkum kvartéru na Chlumu u Srbska: historie a současný stav. Český Kras (Geologie, Paleontologie, Speleologie), 42, 5-22.

Howell, F. C., \& Petter, G. (1979). Diversification et affinités des carnivores pliocènes du groupe de l'Omo et de la formation d'Hadar (Ethiopie). Bulletin de la Société Géologique de France, 21(7), 289-293.

Howell, F. C., \& Petter, G. (1980). The Pachycrocuta and Hyaena lineages (Plio-Pleistocene and extant species of the Hyaenidae). The relationships with Miocene ictitheres: Palhyaena and Hyaenictitherium. Geobios, 13, 579-623.

Iosifova, Y., Agadjanian A. (2010): Quaternary climatic changes, stratigraphy, and sedimentology of the Don River basin. In: Titov V.V., Tesakov A.S. (Eds.), Quaternary stratigraphy and palaeontology of the Southern Russia: connections between Europe, Africa and Asia. Abstracts of the International Union for Quaternary Research-Section on European Quaternary Stratigraphy (INQUA-SEQS) Conference. Rostov on Don, June 21-26, 2010, pp. 61-62.

Jánossy, D. (1986). Pleistocene vertebrae faunas of Hungary (p. 206). Budapest: Akademiai Kiado.

Jánossy, D. (1987). Ältestpleistozäne Vertebratenfauna von Beremend 15 (Süd-Ungarn). Fragmenta Mineralogica et Palaeontologica, 13, 89-96.

Jánossy, D. (1990): Vertebrate fauna of site II. In: Kretzoi, M., Dobosi, V. (Eds.), Vertesszölös. Site, man and culture. Akadémiai Kiado, Budapest, 187-230.

Kahlke, H.-D. (1961). Revision der Säugetierfaunen der klassischen deutschen Pleistozän-Fundstellen von Süßenborn, Mosbach und Taubach. Geologie, 10, 493-529.

Kahlke, H.-D. (1975). The macrofaunas of continental Europe during the Middle Pleistocene: stratigraphic sequence and problems of intercorrelation. In W. Karl, K. W. Butzer, L. Glynn, \& G. L. Isaac (Eds.), After the Australopithecines: stratigraphy, ecology and culture change in the Middle Pleistocene (pp. 309-374). Berlin: De Gruyter Mouton.

Kahlke, R.-D. (2000). The Early Pleistocene (Epivillfranchian) faunal site of Untermassfeld (Thuringia, Central Germany): synthesis of new results. Eraul, 92, 123-138.

Kahlke, R.-D., \& Gaudzinski, S. (2005). The blessing of a great flood: differentiation of mortality patterns in the large mammal record of the Lower Pleistocene fluvial site of Untermassfeld 
(Germany) and its relevance for the interpretation of faunal assemblages from archaeological sites. Journal of Archaeological Science, 32(8), 1202-1222.

Kahlke, R.-D., García, N., Kostopoulos, D. S., Lacombat, F., Lister, A. M., Mazza, P. P. A., et al. (2011). Western Palaearctic palaeoenvironmental conditions during the Early and early Middle Pleistocene inferred from large mammal communities, and implications for hominin dispersal in Europe. Quaternary Science Reviews, 30(11-12), 1368-1395.

Koenigswald, W.v., Heinrich, W.-D. . (1999). Mittelpleistozäne Säugetierfaunen aus Mitteleuropa-der Versuch einer biostratigraphischen Zuordnung. Kaupia, 9, 53-112.

Kojamkulova, B. S., Savinov, P. F., Tutkova, L. A., \& Pak, T. K. (1987). The mammals of the Aktogai locality. Materials of the history of fauna and flora of Kazakhstan, 9, 82-120.

Kolfschoten, T.v., Markova, A.K., (2005): Response of the European mammalian fauna to the mid-Pleistocene transition. In: Head, J.J., Gibbard, P.L. (Eds.), Early-Middle Pleistocene transitions: the land-ocean Evidence. Special Publications of the Geological Society of London 247, 221-229.

Konidaris, G. E., Tourloukis, V., Kostopoulos, D. S., Thompson, N., Giusti, D., Michailidis, D., et al. (2015). Two new vertebrate localities from the Early Pleistocene of Mygdonia Basin (Macedonia, Greece): preliminary results. Comptes Rendus Palevol, $14,353-362$.

Kostopoulos, D.S., Vassiliadou, K., Koufos, G.D. (2002): The beginning of Pleistocene in the Balkan area according to the mammal record; palaeozoogeographical approach. Annales Géologiques des Pays Helléniques 39(A), 253-278.

Koufos, G. D. (2014). The Villafranchian carnivoran guild of Greece: implications for the fauna, biochronology and paleoecology. Integrative Zoology, 9, 444-460.

Koufos, G. D. (2018). New material and revision of the Carnivora, Mammalia from the Lower Pleistocene locality Apollonia 1. Quaternary, 1(6), 1-38.

Koufos, G. D., \& Kostopoulos, D. S. (1997). New carnivore material from the Plio-Pleistocene of Macedonia (Greece) with the description of a new canid. Müncher Geowissenschaftliche Abhandlungen, Reihe A: Geologie und Paläontologie, 34, 33-63.

Koufos, G. D., \& Kostopoulos, D. S. (2016). The Plio-Pleistocene lrge mammal record of Greece: Implications for early human dispersals into Europe. In K. Harvati \& M. Roksanic (Eds.), Palaeoanthropology of the Balkans and Anatolia: human evolution and its context (pp. 269-280). Dordrecht: Springer.

Kovalchuk, O. M. (2017). Regional fish-based biostratigraphy of the Late Neogene and Pleistocene of southeastern Europe. Vestnik Zoologii, 51(5), 375-392.

Kovalchuk, O. M., Wilson, M. V. H., \& Grande, T. (2017). A review of Neogene and Quaternary pikes of southeastern Europe and a new species from the early Pleistocene of Nogaisk Ukraine. Acta Palaeontologica Polonica, 62(1), 121-135.

Kowalski, K. (2001). Pleistocene rodents of Europe. Folia Quaternaria, 72, 3-389.

Kretzoi, M. (1938). Die Raubtiere von Gombaszög nebst einer Übersicht der Gesamtfauna. Annales Historico-Naturales Musei Nationalis Hunagrici, Pars Mineralogica, Geologica et Palaeontologica, 31, 88-157.

Kretzoi, M. (1941). Weitere Beiträge zur Kenntnis der Fauna von Gombaszög. Annales Historico-Naturales Musei Nationalis Hunagrici, Pars Mineralogica, Geologica et Palaeontologica, 34, 105-139.

Kretzoi, M. (1954). Jelentés a kislángi kalabriai (villafrankai) fauna feltárásáról. Állami Földtani Intézet Évijjelentése az, 1, 239-265.
Kretzoi, M. (1965). Die Nager und Lagomorphen von Voigstedt und ihre chronologische Aussage. Paläontologische Abhandlungen, Abteilung A, 2, 585-663.

Krokhmal, A. (2010): Morphogenesis of Allophaiomys teeth - the basis of European Pleistocene. In: Titov V.V., Tesakov A.S. (Eds.), Quaternary stratigraphy and palaeontology of the Southern Russia: connections between Europe, Africa and Asia. Abstracts of the International Union for Quaternary Research-Section on European Quaternary Stratigraphy (INQUA-SEQS) Conference. Rostov-on-Don, June 21-26, 2010, 85-87.

Kurtén, B. (1968). Pleistocene Mammals of Europe (p. 317). London: Weidenfeld and Nicholson.

Kurtén, B. (1972). Fossil Hyaenidae from the excavations at Strànska Skàla. Anthropos, 20, 113-120.

Kurtén, B., \& Garevski, R. (1989). Giant hyaena, Hyaena brevirostris Aymard (Mammalia, Carnivora), from the Middle Pleistocene of Manastirec, Yugoslavia. Annales Zoologici Fennici, 26, 145-147.

Kurtén, B., \& Poulianos, A. N. (1977). New stratigraphic and faunal material from Petralona Cave with special reference to the Carnivora. Anthropos, 4, 47-130.

Kurtén, B., \& Poulianos, A. N. (1981). Fossil carnivora of Petralona Cave: status of 1980. Anthropos, 8, 9-56.

Larramendi Asier, A. (2016). Shoulder height, body mass and shape of proboscideans. Acta Palaeontologica Polonica, 61(3), 537-574.

Leakey, M. D., \& Hay, R. L. (1979). Pliocene footprints in the Laetoli Beds at Laetoli, northern Tanzania. Nature, 278, 317-323.

Lewis, M., Pacher, M., \& Turner, A. (2010). The larger Carnivora of the West Runton Freshwater Bed. Quaternary International, $228,116-135$.

Lundholm, B. A. (1952). Skull of a Cape lioness (Felis leo melanochaitus H. Smith). Annales of the Transvaal Museum, 22, 21-24.

Louys, J. (2014). The large terrestrial carnivore guild in Quaternary Southeast Asia. Quaternary Science Reviews, 96, 86-97.

Lumley, H. D., Kahlke, H. D., Moigne, A. M., \& Moulle, P. E. (1988). Les faunes de grands mammifères de la grotte du Vallonet Roquebrune-Cap-Martin Alpes-Maritimes. L'Anthropologie, 92(2), 465-496.

Madurell-Malapeira, J., Alba, D. M., Espigares, M.-P., Vinuesa, V., Palmqvist, P., Martínez-Navarro, B., \& Moya-Solà, S. (2017). Were large carnivorans and great climatic shifts limiting factors for hominin dispersals? Evidence of the activity of Pachycrocuta brevirostris during the Mid-Pleistocene Revolution in the Vallparadís Section (Valles-Penedès Basin, Iberian Peninsula). Quaternary International, 431, 42-52.

Madurell-Malapeira, J., Alba, D. M., \& Moyà-Solà, S. (2009a). Carnivora from the Late Early Pleistocene of Cal Guardiola (Terrassa, Vallès-Penedès Basin, Catalonia, Spain). Journal of Paleontology, 83(6), 969-974.

Madurell-Malapeira, J., Aurell, J., Alba, D. M., \& Moyà-Solà, S. (2009b). Los niveles fosilíferos epivillafranchienses de Vallparadís (Terrassa, Barcelona, España). Paleolusitana, 1, 237-243.

Madurell-Malapeira, J., Minwer-Barakat, R., Martínez, A. D., Garcés, M., Gómez, M., Aurell-Garrido, J., et al. (2010). The Vallparadís section (Terrassa, Iberian Peninsula) and the latest Villafranchian faunas of Europe. Quaternary Science Reviews, 29, 3972-3982.

Madurell-Malapeira, J., Morales, J., Vinuea, V., \& Boscaini, A. (2015). Úrsidos, hiénidos y félidos del Pleistoceno inferior de Cueva Victoria (Cartagena, Murcia). Mastia Revista del Museo Arqueológico Municipal de Cartagena Geología y Paleontología de Cueva Victoria, 11-13, 401-433.

Madurell-Malapeira, J., Ros-Montoya, S., Espigares, M. P., Alba, D. M., \& Aurell-Garrido, J. (2014). Villafranchian large mammals from the Iberian Peninsula: paleobiogeography, paleoecology 
and dispersal events. Journal of Iberian Geology, 40(1), $167-178$.

Marciszak, A. (2014). Presence of Panthera gombaszoegensis (Kretzoi, 1938) in the late Middle Pleistocene of Biśnik Cave, Poland, with an overview of Eurasian jaguar size variability. Quaternary International, 326-327, 104-113.

Markova, A. K. (2007). Pleistocene mammal faunas of Eastern Europe. Quaternary International, 60(1), 100-111.

Markova, A. K., \& Vislobokova, I. A. (2016). Mammal faunas in Europe at the end of the Early - beginning of the Middle Pleistocene. Quaternary International, 420, 363-377.

Martínez-Navarro, B. (1992). Revisión sistemática de la fauna de macromamíferos del yacimiento de Venta Micena (Orce, Granada, España). In J. Gibert (Ed.), Presencia humana en el Pleistoceno inferior de Granada y Murcia (pp. 21-86). Ayuntamiento de Orce: Granada.

Martinez-Navarro, B., Belmaker, M., \& Bar-Yosef, O. (2009). The large carnivores from Ubeidiya (early Pleistocene, Israel): biochronological and biogeographical implications. Journal of Human Evolution, 56, 514-524.

Martínez-Navarro, B., Espigares, M.P., Ros, S. (2003): Estudio preliminary de las asociaciones de grandes mamíferos de Fuente Nueva-3 y Barranco León-5 (Orce, Granada, España) (informe de las campañas de 1999-2002). In: Toro, I., Agustí, J., MartínezNavarro, B. (Eds.), El Pleistoceno inferior de Barranco León y Fuente Nueva 3, Orce (Granada). Memoria Científica Campañas 1999-2002. Junta de Andalucía. Consejería de Cultura. E.P.G. Arqueología Monográfico, 115-136.

Martínez-Navarro, B., \& Palmqvist, P. (1996). Presence of the African saber-toothed felid Megantereon whitei (Broom, 1937) (Mammalia, Carnivora, Machairodontinae) in Apollonia-1 (Mygdonia basin, Macedonia, Greece). Journal of Archaeological Science, $23,869-872$.

Martínez-Navarro, B., Toro, I., \& Agustí, J. (2004). Las asociaciones de grandes mamíferos de Fuente Nueva-3 y Barranco León-5 (Orce, Granada, España): Resultados preliminares. In E. Baquedano \& S. Rubio (Eds.), Miscelánea Homenaje a Emiliano Aguirre, Paleontología, Museo Arqueológico Regional (pp. 292-305). Madrid: Alcalá de Henares.

Martínez-Navarro, B., Palmqvist, P., Madurell, J., Ros-Montoya, S., Espigares, M.P., Torregrosa, V., Pérez-Claros, J. A. (2010): La fauna de grandes mamíferos de Fuente Nueva 3 y Barranco León 5. Estado de la cuestión. In: Toro, I., Martínez-Navarro, B., Agustí, J. (Eds.), Ocupaciones Humanas en el Pleistoceno inferior y medio de la cuenc de Guadix-Baza, Memoria Científica. Junta de Andalucía. Consejería de Cultura. E.P.G. Arqueología Monográfico, 197-236.

Maschenko, E. N., Schvyreva, A. K., \& Kalmykov, N. P. (2011). The second complete skeleton of Archidiskodon meridionalis (Elephantidae, Proboscidea) from the Stavropol Region, Russia. Quaternary Science Reviews, 30, 2273-2288.

Mäuser, M. (1987). Geologische Und Palaontologische Untersuchungen an der Altpleistozanen Saugetier-Fundstelle WürzburgSchalksberg (p. 77). München: Pfeil.

Mazza, P. P. A., Bertini, A., \& Magi, M. (2004). The Late Pliocene site of Poggio Rosso (Central Italy): taphonomy and palaeoenvironment. Palaios, 19(3), 227-248.

Medin, T., Martínez-Navarro, B., Rivals, F., Madurell-Malapeira, J., Ros-Montoya, S., Espigares, M.-P., et al. (2017). Late Villafranchian Ursus etruscus and other large carnivorans from the Orce sites (Guadix-Baza basin, Andalusia, southern Spain): taxonomy, biochronology, paleobiology, and ecogeographical context. Quaternary International, 431B, 20-41.

Moreno-García, D. (2011): Datation par ESR de quartz optiquement blanchis (ESR-OB) de la région de Atapuerca (Burgos, Espagne). Application au site préhistorique de Gran Dolina (contexte karstique) et aux systèmes fluviatiles quaternaires de l'Arlanzón et l'Arlanza. Unpublished Ph. D. Thesis, Universitat Rovira i Virgili, Tarragona, Spain, 305 p.

Moullé, P.-E. (1992): Les grands mammifères de la grotte du Pléistocène inférieur de la grotte du Vallonnet (Roq Brune, Cap Martin, Alpes Maritimes). Étude paléontologique des Carnivores, Equidae, Suidae et Bovidae. Ph.D. dissertation, Muséum National d'Histoire Naturelle, Paris, 365p.

Moullé, P.-E. (1998). Les grandes mammifères de la grotte du Vallonnet (Roquebrune-cap-martin): synthèse des etudes antérieures et nouvelles dèterminations. Bulletin de Musée d'Anthropologie Préhistorique de Monaco, 39, 29-36.

Moullé, P.-E., \& Tréguier, J. (2006). Comparaison des dents déciduales de Pachycrocuta brevirostris et de Crocuta crocuta spelaea. Bulletin du Musée d'Anthropologie Préhistorique de Monaco, 46, 20-34.

Musil, R. (1995): Large fauna of talus cones at the Stránská Skála Hill. In: Musil, R. (Ed.), Stránská Skála Hill. Excavations of openair sediments 1964-1972. Anthropos Neue Serie 26(18), 65-83.

Mutter, R. J., Berger, L. R., \& Schmidt, P. (2001). New evidence of the giant hyaena, Pachycrocuta brevirostris (Carnivora, Hyaenidae), from the Gladysvale Cave deposit (Plio-Pleistocene, John Nash Nature Reserve, Gauteng, South Africa). Palaeontologia Africana, 37, 103-113.

Nikivorova, K. W., Bejleva, E. I., Bangengejm, E. A., Konstantinova, N. A., \& Niegadajew-Nikonow, K. N. (1971). Plejstocen Tiraspolja. Otdel paleontologii i stratigrafii: Akademia Nauk Moldavskoi SSR.

Ozansoy, F. (1965). Étude des gisements continentaux et des Mammifères du Cénozoique de Turquie. Memoires de la Societé Geologique de France, 102, 1-92.

Palmqvist, P., Martínez-Navarro, B., \& Arribas, A. (1996a). Prey selection by terrestrial carnivores in a lower Pleistocene paleocommunity. Paleobiology, 22(4), 514-534.

Palmqvist, P., Martínez-Navarro, B., \& Arribas, A. (1996b). Prey selection by terrestrial carnivores in a lower Pleistocene paleocommunity. Paleobiology, 22, 514-534.

Palmqvist, P., \& Arribas, A. (2001a). Taphonomic decoding of the paleobiological information locked in a lower Pleistocene assemblage of large mammals. Paleobiology, 27(3), 512-530.

Palmqvist, P., \& Arribas, A. (2001b). Taphonomic decoding of the paleobiological information locked in a lower Pleistocene assemblage of large mammals. Paleobiology, 27, 512-530.

Palmqvist, P., Martínez-Navarro, B., Pérez-Claros, J. A., Torregrosa, V., Figueirido, B., Jiménez-Arenas, J. M., et al. (2011). The giant hyena Pachycrocuta brevirostris: modelling the bone-cracking behaviour of an extinct carnivore. Quaternary International, 243(1), 61-79.

Palmqvist, P., Gröcke, D. R., Arribas, A., \& Fariña, R. A. (2003). Paleoecological reconstruction of lower Pleistocene large mammal community using biogeochemical $\left(\delta^{13} \mathrm{C}, \delta^{15} \mathrm{~N}, \delta^{18} \mathrm{O}, \mathrm{Sr}: \mathrm{Zn}\right)$ and ecomorphological approaches. Paleobiology, 29, 205-229.

Palmqvist, P., Martínez-Navarro, B., Toro, I., Espigares, M.P., RosMontoya, S., Torregrosa, V., Pérez-Claros, J.A. (2005): A reevaluation of the evidence of human presence during Early Pleistocene times in south-eastern Spain. L'Anthropologie 109, 411-450.

Palombo, M. R., \& Valli, A. M. F. (2004). Remarks on the biochronology of mammalian faunal complexes from the Pliocene to the Middle Pleistocene in France. Geologica Romana, 37, 145-163.

Pavlow, M. W. (1925). Mammiferes fossiles du gravier de Tiraspol gouvernement de Kherson. Memoires de la Section Geologique de la Societe des Amis des Sciences Naturelles, d'Anthropologie et d'Ethnographie, 3, 1-76.

Petrucci, M., Cipullo, A., Martínez-Navarro, B., Rook, L. Sardella, R. (2013): The late Villafranchian (Early Pleistocene) carnivores 
(Carnivora, Mammalia) from Pirro Nord (Italy). Palaeontographica Abteilung A: Paläozoologie-Stratigraphie 298(1), 113-145.

Pons-Moyà, J. (1987). Los carnívoros (Mammalia) de Venta Micena (Granada, España). Paleontologia i Evolució, 1, 109-128.

Pons-Moyà, J., \& Moyà-Solà, S. (1978). La fauna de Carnívoros del Pleistoceno medio (Mindel) de la Cueva Victoria (Cartagena, España). Acta Geológica Hispánica, 13, 54-58.

Popescu, A. (2011). The tarsals of Mammuthus meridionalis (Nesti, 1825) from Leu (Dolj County, Romania. Geo-Eco-Marina, 17, 211-217.

Qiu, Z. (1987). Die Hyaeniden aus dem Ruscinium und Villafranchium Chinas. Münchner Geowissenschaftlichen Abhandlungen A, 9, $1-108$.

Randall, R. M. (1981). Fossil Hyaenidae from the Makapansgat limeworks deposit, South Africa. Palaeontologia Africana, 24, $75-85$.

Rekovets, L. I. (1994). Small mammals of the Anthropogene of the southern part of East Europe (p. 370). Kiev: Naukova Dumka.

Rekovets, L. I., Kopij, G., \& Nowakowski, D. (2009). Taxonomic diversity and spatiotemporal distribution of late Cenozoic beavers (Castoridae, Rodentia) of Ukraine. Acta Zoologica Cracoviensia, 52A(1-2), 95-105.

Rekovets, L., \& Nadachowski, A. (1996). Pleistocene voles (Arvicolidae) of the Ukraine. Paleontologia i Evolució, 28-29, 145-245.

Rook, L., Croitor, R., Delfino, M., Ferretti, M. P., Gallai, G., \& Pavia, M. (2013). The Upper Valdarno Plio-Pleistocene vertebrate record: an historical overview, with notes on palaeobiology and stratigraphic significance of some important taxa. Bollettino della Società Geologica Italiana, 132(1), 104-125.

Schaefer, H. (1969). Carnivores from the Pleistocene of Süssenborn, Germany. Palaeontographica Abteilung A, 3, 757-760.

Shchelinsky, V. E., Dodonov, A. E., Baigusheva, V. S., Kulakov, S. A., Simakova, A. N., Tesakov, A. S., \& Titov, V. V. (2010). Early Palaeolithic sites on the Taman Peninsula (Southern Azov Sea region, Russia): Bogatyri/Sinyaya Balka and Rodniki. Quaternary International, 223-224, 28-35.

Schütt, G. (1971). Die Hyänen der Mosbacher Sande (Altpleistozän, Wiesbaden/ Hessen) mit einem Beitrag zur Stammesgeschichte der Gattung Crocuta. Mainzer naturwissenschaftliches Archiv, $10,29-76$.

Schütt, G. (1972): Fossil mammals of Java. IV. Zur kenntnis der Pleistozänen hyanen Javas, Proceedings Koninklijke Nederlandse Akademie van Wetenschappen Serie B 74, 261-288.

Schütt, G. (1974). Die Carnivoren von Würzburg-Schalksberg. Mit einem Beitrag zur biostratigraphischen und zoogeographischen Stellung der altpleistozänen Wirbeltierfauna vom Mittelmain (Unterfranken). Neues Jahrbuch für Geologie und Paläontologie Abhandlungen, 147(1), 61-90.

Sesé, C., \& Ruiz-Bustos, A. (1992). Nuevas faunas de micromamíferos del Pleistoceno del norte de la provincia de Madrid (España). Boletín de la Real Sociedad Española de Historia Natural, 87, 115-139.

Soergel, W. (1936). Hyaena brevirostris Aymard und Hyaena ex. aff. crocotta Erxl. aus den Kiesen von Süßenborn. Zeitschrift der Deutschen Geologischen Gesellschaft, 88, 525-539.

Soto, E., \& Morales, J. (1985). Grandes mamíferos del yacimiento Villafranquiense de Casablanca-1, Almenara (Castellón). Estudios Geológicos, 41, 243-249.

Sotnikova, M. (1989). Late Pliocene-Early Pleistocene Carnivora: stratigraphic significance. Transactions of the Academic Science of the Union of Soviet Socialist Republics, 140, 1-123.

Sotnikova, M. V., Bajgusheva, V. S., \& Titov, V. V. (2002). Carnivores of the Khapry faunal assemblage and their stratigraphic implications. Stratigraphy and Geological Correlation, 10(4), 62-78.

Sotnikova, M. V., Dodonov, A. E., \& Pen'kov, A. V. (1997). Upper Cenozoic bio-magnetic stratigraphy of Central Asian mammalian localities. Palaeogeography, Palaeoclimatology, Palaeoecology, 133, 243-258.

Sotnikova, M., \& Titov, V. (2009). Carnivora of the Tamanian faunal unit (the Azov Sea area). Quaternary International, 201, 43-52.

Sotnikova, M. V., \& Vislobokova, I. A. (1990). Pleistocene mammals from Lakhuti, southern Tajikistan, U.S.S.R. Quartärpaläontologie, 8, 237-244.

Stefen, C., \& Rensberger, J. M. (2002). The specialized enamel structure of hyaenids (Mammalia, Hyaenidae): description and development within the lineage - including pecrocutids. Zoologische Abhandlungen, 52, 127-147.

Stehlík, A. (1934). Fossilní ssavci ze Stránské skály u Brna. Práce moravské přirodovědecké společnosti, 9, 1-94.

Steensma, K.J. (1988): Plio-/Pleistozäne Großäugetiere (Mammalia) aus dem Becken von Kastoria/Grevena, südlich von NeapolisNW Griechenland. Ph.D. dissertation, Technische Universität Clausthal, $457 \mathrm{p}$.

Stuart, A. J., \& Lister, A. M. (2010). The West Runton Freshwater Bed and the West Runton Mammoth: summary and conclusions. Quaternary International, 228, 241-248.

Teilhard de Chardin, P., \& Piveteau, J. (1930). Les mammifères fossiles de Nihowan (Chine). Annales de Paléontologie, 19, 3-134.

Tesakov, A. S. (2004). Biostratigraphy of the Middle Pliocene-Eopleistocene of Eastern Europe (based on small mammals) (p. 248). Moscow: Nauka.

Tesakov, A. S., Dodonov, A. E., Titov, V. V., \& Trubikhin, V. M. (2007). Plio-Pleistocene geological record and small mammal faunas, eastern shore of the Azov Sea, Southern European Russia. Quaternary International, 160, 57-69.

Tesakov, A.S., Titov, V.V., Baygusheva, V.S., Velichko, A.A., Timireva, S.N., Simakova, A.N., Borisova, O.K., Morozova, T.D., Semenov, V.V., Syromyatnikova, E.V., Shishkov, V.A., Kononov, Y.M., Konstantinov, E.A., Kurbanov, R.N., Kurshakov, S.V., Frolov, P.D. (2013): VIII All-Russian Conference on Quaternary research: basic problems of Quaternary, research results, and the main trends of future studies. Field Excursions Guidebook (Rostov-on-Don, Russia, 10-15 June 2013). SSC RAS Publishing, Rostov-on-Don, $48 \mathrm{p}$.

Titov, V. V. (2008). Late Pliocene large mammals from north-eastern Sea of Azov region (p. 264). Rostov-on-Don: SSC RAS Publishing.

Topachevsky, V. A. (1957). New species of ground squirrels from upper Pliocene sediments near Azov Sea. Dopovidi Akademii Nauk Ukrainskoi RSR, 1957, 204-208.

Topachevsky, V. A. (1965). Insectivores and rodents of the late Pliocene fauna at Nogaisk (p. 164). Kiev: Naukova Dumka.

Topachevsky, V. A., Skorik, A. F., \& Rekovets, L. I. (1987). Rodents of the upper Neogene and early Anthopogene sediments of Khadzhibejskiy Liman (p. 207). Kiev: Naukova Dumka.

Toerien, M. J. (1952). The fossil hyenas of the Makapansgat valley. South African Journal of Science, 48, 293-300.

Torre, D., Albianelli, A., Azzaroli, A., Ficcarelli, G., Magi, M., Napoleone, G., \& Sagri, M. (1993). Paleomagnetic calibration of the Late Villafranchian mammalian faunas from the Upper Valdarno, Central Italy. Memorias Societa Geologica Italiana, 49, 335-344.

Tsoukala, E., \& Bonifay, M.-F. (2004). The early Pleistocene carnivores (Mammalia) from Ceyssaguet (Haute-Loire). Paléo, 6, 193-241.

Tsoukala, E., \& Chatzopoulou, K. (2005). A new Early Pleistocene (latest Villafranchian) site of large mammals in Kalamoto of the Mygdonia basin (Macedonia, Greece). Preliminary report. Mitteilungen der Kommission für Quartärforschung Österreich Akademie der Wissenschaften, 14, 213-233. 
Tuccimei, G. (1896). Sopra i resti fossili di mammiferi trovati alla Villa Spinola presso Perugia. Atti della Accademia pontificia de nuovi Lincei, 48, 44-46.

Turner, A. (1987). New fossil carnivore remains from the Sterkfontein hominid site (Mammalia: Carnivora). Annals of the Transvaal Museum, 34(15), 319-347.

Turner, A. (1995). Evidence for Pleistocene contact between the British Isles and the European continent based on distributions of larger carnivores. In R. C. Preece (Ed.), Island Britain: a Quaternary perspective (pp. 141-149). London: The Geological Society.

Turner, A. (1999). Larger carnivores (Mammalia, Carnivora) from Westbury Cave. In P. Andrews, J. Cook, C. Stringer, \& A. Currant (Eds.), Westbury Cave: The Natural History Museum Excavations 1976-1984 (pp. 175-193). Bristol: Western Academic and Specialist Press.

Turner, A. (2001). Remains of Pachycrocuta brevirostris (Carnivora, Hyaenidae) from the Lower Pleistocene site of Untermassfeld. Jahrbuch des Römisch-Germanischen Zentralmuseums Mainz, 2, 673-690.

Turner, A. (2009). The evolution of the guild of large Carnivora of the British Isles during the Middle and Late Pleistocene. Journal of Quaternary Science, 24(8), 991-1005.

Turner, A., \& Antón, M. (1996). The giant hyaena Pachycrocuta brevirostris (Mammalia, Carnivora, Hyaenidae). Geobios, 29, 455-468.

Turner, A., Antón, M., \& Werdelin, L. (2008). Taxonomy and evolutionary patterns in the fossil Hyaenidae of Europe. Geobios, 41, 677-687.

Turq, A., Martínez Navarro, B., Palmqvist, P., Arribas, A., Agustí, J., \& Rodríguez Vidal, J. (1996). Le Plio-Pleistocène de la région d'Orce, Province de Grenade, Espagne: bilan et perspectives de recherche. Paléo, 8, 161-204.

Vangengeim, E. A., Vekua, M. L., Zhegallo, V. I., Pevzner, M. A., Taktakishvili, I. G., \& Tesakov, A. S. (1991). Position of the Tamanian Faunal complex in the stratigraphic and magnitochronological scales. Bulletin of the Commission for Study of the Quaternary, 60, 41-52.

Velichko, A., Catto, N., Tesakov, A., Titov, V., Morozova, T., (2010): The structure of Pleistocene loess-paleosol formation in Southern Russian plain based on data from Eastern Azov Sea region. In: Titov V.V., Tesakov A.S. (Eds.), Quaternary stratigraphy and palaeontology of the Southern Russia: connections between Europe, Africa and Asia: Abstracts of the International Union for Quaternary Research-Section on European Quaternary Stratigraphy (INQUA-SEQS) Conference. Rostov on Don, June 21-26, 2010, 184-187.

Vereshchagin, N. K. (1957). Remains of mammals from the Lower Quaternary deposits of the Taman Peninsula. Transactions of the Zoological Institute of the Academy of Sciences of the USSR, 22, 9-74.

Vereshchagin, N. K. (1959). Mammals of the Caucasus (p. 764). Moscow-Leningrad: Academy of Sciences of the USSR.

Vereshchagin, N., Alekseeva, L., David, A., \& Baigusheva, V. (1971). Genus Pontoceros. In K. Nikiforova (Ed.), Pleistocene of Tiraspol (pp. 167-170). Shtiinsa: Kishinev.

Vinuesa, V., Iurino, D. A., Madurell-Malapeira, J., Liu, J., Fortuny, J., Sardella, R., \& Alba, D. M. (2016). Inferences of social behavior in bone-cracking hyaenids (Carnivora, Hyaenidae) based on digital paleoneurological techniques: Implications for humancarnivoran interactions in the Pleistocene. Quaternary International, 413B, 7-14.

Viseras, C., Soria, J. M., Durán, J. J., Pla, S., Garrido, G., GarcíaGarcía, F., \& Arribas, A. (2006). A large mammal site in a meandering fluvial context (Fonelas P-1, Late Pliocene, Guadix Basin, Spain). Sedimentological keys for its palaeoenvironmental reconstruction. Palaeogeography, Palaeoclimatology, Palaeoecology, 242, 139-168.

Vislobokova, I. (2005). On Pliocene faunas with proboscideans in the territory of the former Soviet Union. Quaternary International, 126-128, 93-105.

Vislobokova, I. A., \& Agadjanian, A. K. (2015). New data on large mammals of the Pleistocene Trlica fauna, Montenegro, the Central Balkans. Paleontological Journal, 6, 86-102.

Vislobokova, I., \& Tesakov, A. (2013). Early and Middle Pleistocene of Northern Eurasia. In S. A. Elias (Ed.), The Encyclopaedia of Quaternary Sciences (pp. 605-614). Amsterdam: Elsevier.

Vislobokova, I. A., \& Titov, V. V. (2020). Spiral-horned antelopes of the Early Pleistocene Tamanian faunal complex of Eastern Europe. Russian Journal of Theriology, 19(1), 37-44.

Werdelin, L. (1999). Pachycrocuta (hyaenids) from the Pliocene of east Africa. Paläontologische Zeitschrift, 73(1/2), 157-165.

Werdelin, L., \& Lewis, M. E. (2000). Carnivora from South Turkwel Hominid site Northern Kenya. Journal of Palaeontology, 74(6), 1173-1180.

Werdelin, L., \& Lewis, M. E. (2005). Plio-Pleistocene Carnivora of eastern Africa: species richness and turnover patterns. Zoological Journal of the Linnean Society, 144, 121-144.

Werdelin, L., \& Lewis, M. E. (2008). New species of Crocuta from the early Pliocene of Kenya, with an overview of early Pliocene hyenas of eastern Africa. Journal of Vertebrate Paleontology, $28,1162-1170$.

Publisher's Note Springer Nature remains neutral with regard to jurisdictional claims in published maps and institutional affiliations. 